Article

\title{
On the Retrofit of Existing Buildings with Aerogel Panels: Energy, Environmental and Economic Issues
}

\author{
Paola Marrone ${ }^{1}$, Francesco Asdrubali ${ }^{2, *}$, Daniela Venanzi ${ }^{3}{ }^{\circledR}$, Federico Orsini ${ }^{1}$, Luca Evangelisti ${ }^{2}$, \\ Claudia Guattari ${ }^{2}$, Roberto De Lieto Vollaro ${ }^{2} \mathbb{D}$, Lucia Fontana ${ }^{1}$, Gianluca Grazieschi ${ }^{2} \mathbb{D}$, Paolo Matteucci $^{3}$ \\ and Marta Roncone ${ }^{2}$ (D)
}

1 Department of Architecture, Roma TRE University, via Madonna dei Monti 40, 00184 Rome, Italy; paola.marrone@uniroma3.it (P.M.); federico.orsini@uniroma3.it (F.O.); lucia.fontana@uniroma3.it (L.F.)

2 Department of Engineering, Roma TRE University, via Vito Volterra 62, 00146 Rome, Italy; luca.evangelisti@uniroma3.it (L.E.); claudia.guattari@uniroma3.it (C.G.); roberto.delietovollaro@uniroma3.it (R.D.L.V.); gianluca.grazieschi@uniroma3.it (G.G.); marta.roncone@uniroma3.it (M.R.)

3 Department of Economics, Roma TRE University, via Silvio D'Amico 77, 00145 Rome, Italy; daniela.venanzi@uniroma3.it (D.V.); paolo.matteucci@uniroma3.it (P.M.)

* Correspondence: francesco.asdrubali@uniroma3.it

check for updates

Citation: Marrone, P.; Asdrubali, F.; Venanzi, D.; Orsini, F.; Evangelisti, L.; Guattari, C.; De Lieto Vollaro, R.;

Fontana, L.; Grazieschi, G.; Matteucci, P.; et al. On the Retrofit of Existing Buildings with Aerogel Panels: Energy, Environmental and Economic Issues. Energies 2021, 14, 1276. https://doi.org/10.3390/en14051276

Academic Editor: Paulo Santos

Received: 19 January 2021

Accepted: 22 February 2021

Published: 25 February 2021

Publisher's Note: MDPI stays neutral with regard to jurisdictional claims in published maps and institutional affiliations.

Copyright: (c) 2021 by the authors. Licensee MDPI, Basel, Switzerland. This article is an open access article distributed under the terms and conditions of the Creative Commons Attribution (CC BY) license (https:/ / creativecommons.org/licenses/by/ $4.0 /)$.

\begin{abstract}
Among the super insulating materials, aerogel has interesting properties: very low thermal conductivity and density, resistance to high temperatures and transparency. It is a rather expensive material, but incentives in the field can improve its economic attractiveness. Starting from this, the thermal behavior of a test building entirely insulated with aerogel panels was investigated through an extended experimental campaign. A dynamic simulation model of a case study building was generated to better comprehend the energy savings obtained through aerogel in terms of energy demand over a whole year. The investigation was completed by computing the carbon and energy payback times of various retrofit strategies through a life cycle assessment approach, as well as by a cost-benefit analysis through a probabilistic financial framework. Compared to conventional insulation materials, aerogel is characterized by a higher energy and carbon payback time, but it guarantees better environmental performance in the whole life cycle. From an economic-financial perspective, the aerogel retrofit is the best in the current tax incentive scenario. However, due to its higher lump-sum investment, aerogel's net present value is very sensitive to tax deductions, and it is riskier than the best comparable materials in less favorable tax scenarios.
\end{abstract}

Keywords: aerogel; thermal behavior; dynamic simulation; retrofitting; LCA; economic analysis

\section{Introduction}

Climate-changing gases (GHG), mainly produced by anthropogenic activities, are now considered to be the main responsible factor for the global warming; in fact, the global average temperature has increased by about $1^{\circ} \mathrm{C}$ compared to the pre-industrial era [1]. Consequently, due to global warming and climate change (CC), large and densely populated areas risk becoming inhospitable [2]. To avoid, or at least reduce, the negative effects of climate change, it is necessary to globally modify the development model aiming at reducing GHG emissions [3,4].

This objective can be pursued by promoting renewable resources [5], inspiring economic development to the principles of the circular economy [6-9], producing low-carbon materials [10,11] and reducing energy consumption [12]. In this context, cities and buildings play a fundamental role. They are among the main responsible factors for energy consumption and GHG emissions (over 30\% of the total amount), mainly caused by urban and extra-urban transport, buildings' energy needs (electrical appliances, heating and cooling) and the production of construction materials [13]. 
The European Green Deal set the target of reducing GHG emissions by at least 50-55\% below the levels of 1990 by 2030 [14].

Among the possible actions encouraged by this agreement, strategies to reduce buildings' energy consumption can be listed. In particular, policies targeted at improving the thermal performance of buildings' envelopes $[15,16]$ in terms of reducing heat loss and increasing thermal lag can be implemented.

Alongside the traditional insulator materials [17] made of inorganic constituents (for example, rock wool, expanded polystyrene, etc.), or organic ones (cork, wood fibers, etc.), today non-traditional materials, defined as super-insulating, made with innovative production processes and/or materials, are available [18].

The super-insulating materials are characterized by high performance with a thermal conductivity value lower than $0.020 \mathrm{~W} / \mathrm{mK}$, compared to traditional materials (rock wool or glass wool) whose thermal conductivity is equal to $0.035-0.040 \mathrm{~W} / \mathrm{mK}$. Comparison can also be made with transition materials, such as expanded polyurethane or propylene, characterized by thermal conductivity values ranging between 0.02 and $0.03 \mathrm{~W} / \mathrm{mK}[19,20]$. Furthermore, the high thermal performance of non-traditional insulation materials is characterized by a significant reduction in their thicknesses compared to the traditional ones. Different kinds of innovative and high-insulating materials have already been studied by researchers: reflective multilayer insulation [21-23], vacuum insulation panels (VIPs) [24] and gas-filled panels [25].

Among these innovative materials, aerogel appears to be of great interest, ranking among the most interesting innovative products for the near future [26]. Discovered in the early 1930s $[27,28]$, aerogel is a porous synthetic product, in which the gel's liquid component is replaced with a gas. This solution allowed the creation of a highly performing material in terms of thermal insulation, with a thermal conductivity of about $0.013 \mathrm{~W} / \mathrm{mK}$. In fact, several studies have highlighted its excellent thermal performance for opaque envelope applications, integrated in panels [29,30] or mortars [31], and for translucent applications, integrated in panels and frames [32,33]. Cuce et al. [34] presented a comprehensive review on aerogel utilization in buildings: the applications range from energy insulation purposes, to sound insulation, fire retardation and air purification. The use of aerogel in retrofits of historical buildings is very competitive since it permits saving inner space, maintaining the external façades unaltered [35]. Karim et al. [36] proposed a superinsulated plaster made with aerogel particles mixed in the matrix. Finally, their optical properties permit the integration of aerogels in different types of glazing systems [37].

If, on one hand, the high performance of aerogel is nowadays well-known owing to several studies, on the other hand, these studies have also focused on the high cost of this material [35]. Nowadays, this aspect is considered as a very strong limit to its widespread application to the construction sector [38].

However, in Italy this limit can now be partially overcome thanks to the introduction in Italian law of a tax credit of $90 \%$ (so-called "bonus façades") for the costs incurred for the retrofit of the building façades (see Budget Law 2020). The standard also includes energy retrofit interventions that meet the so-called minimum requirements and the thermal transmittance limit values of the building envelope [39]. Another incentive that is today guaranteed by the Italian legislation is the so called Superbonus $110 \%$ (a tax reduction of the $110 \%$ of the expenditure sustained for the works aiming at deep energy retrofits of existing buildings [40]). The insulation of building envelopes is one of the driving interventions that are promoted by Superbonus $110 \%$.

Starting from this, it seems important to evaluate the possibility of employing aerogel for the energy retrofit of existing buildings in order to define its effectiveness in terms of both thermal performance and economic feasibility.

This paper has the following structure: Section 2 provides the aim and scope of the research; Section 3 provides some information about the test rooms and the case study, the experimental campaign in the test rooms, data post-processing, simulations in a case 
study building and the cost-benefit analysis; Section 4 presents the results; finally, Section 5 draws conclusions.

\section{Aim and Scope}

The thermal performance of aerogel is well-known in the literature. It is a super insulating material able to improve the thermal performance of a wall with reduced thicknesses. On the other hand, aerogel is a rather expensive material, and its use needs a comparison between energy savings and installation costs in order to identify costs and benefits.

Thus, the aim of this study is a wide-ranging analysis, examining and comparing aerogel performance to that of other diffused insulation materials employed as an external insulation layer in regions characterized by a mild climate (central Italy). From an economicfinancial point of view, the analysis here conducted applies a complete financial approach, based on a probabilistic method used to measure both the most probable value of the Net Present Value (NPV) of each retrofit alternative and its probability distribution (however, limited to the monetizable costs and benefits). This approach assumes optimistic and pessimistic estimates (defined in a subjective manner) of the uncertain variables and measures the corresponding range of NPV. Therefore, it derives (under some hypotheses) the variance of the NPV that allows obtaining its probability distribution.

The whole analysis was carried out in order to compare and quantify the advantages/disadvantages of employing aerogel instead of other insulation materials, also in the light of the Italian tax credit.

\section{Materials and Methods}

This work integrates four evaluation fields to assess the competitiveness of aerogel in comparison with other insulation materials. After an experimental campaign aiming at studying the real thermal performance of an aerogel coating insulation (described in Section 3.1), a simulation was carried out to evaluate the energy savings achievable by building retrofits using aerogel or other insulation materials (introduced in Section 3.2); the evaluation of the related environmental benefits in the life cycle (see Section 3.3) and the estimation of the achievable economic benefits (see Section 3.4) were finally performed.

\subsection{The Experimental Campaign}

The experimental measurement campaigns took place in the external area of the CEFME CTP school for construction, located in Pomezia, a small city close to Rome. According to Italian legislation, the climatic zone of Pomezia is D (on a scale from A to F, with A corresponding to the warmest places and $\mathrm{F}$ the coldest), with a degree day value equal to 1536. The experimental investigations involved two test rooms characterized by the same geometry, walls and roof stratigraphy, and the same orientation. One of them is not thermally insulated; the other is insulated with aerogel panels. It is worth noting that the two test rooms, despite their close proximity, do not cast shadows on one another. Figure 1a provides an aerial view of the construction site, and Figure $1 \mathrm{~b}$ shows the geometrical characteristics of the investigated test rooms. Original vertical walls are characterized by brick construction technique, with plastered tuff blocks, reinforced concrete slabs and internal and external cladding with cement plaster. Table 1 lists the stratigraphy of the test rooms' components. 

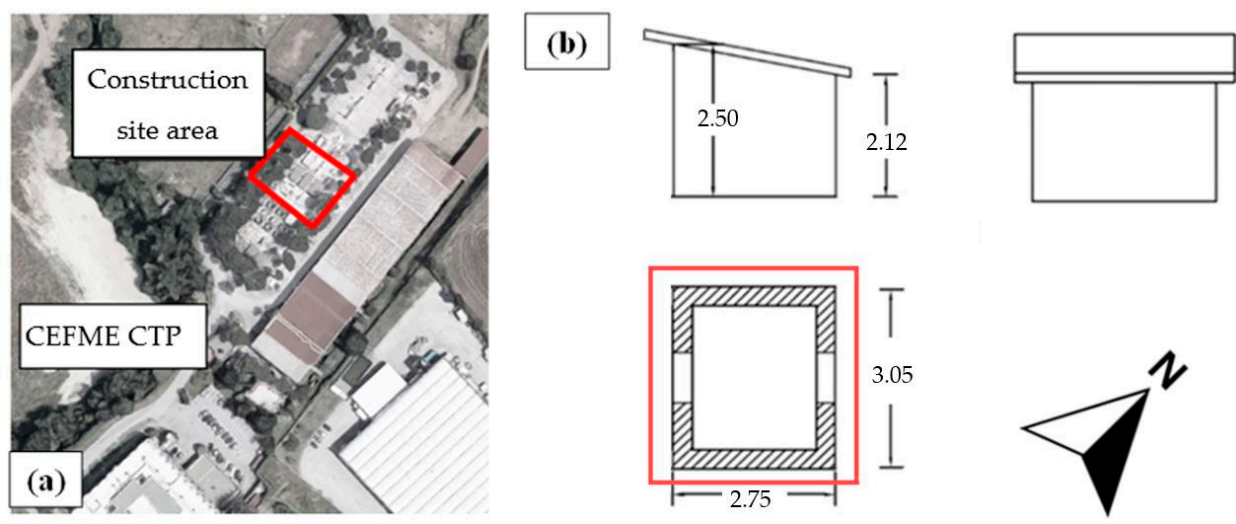

Figure 1. Aerial view of the construction site (a), geometrical characteristics of the monitored test rooms (b).

Table 1. Test Rooms' Components Stratigraphy.

\begin{tabular}{ccc}
\hline Component & Material & Thickness [m] \\
\hline & External cement plaster & 0.04 \\
External wall & Tuff blocks & 0.26 \\
& Internal cement plaster & 0.04 \\
Roof & Reinforced concrete slab & 0.14 \\
Ground floor & Reinforced concrete slab & 0.12 \\
Door & Oak wood & 0.04 \\
\hline
\end{tabular}

Sample images of the analyzed test rooms are reported in Figure 2, where it is possible to observe the external insulation system during installation (aerogel panels characterized by a thickness equal to $0.01 \mathrm{~m}$ ) and after installation. The external insulation layer was realized with semi-rigid panels [41] (dimensions equal to $1400 \times 720 \mathrm{~mm}$ ), realized by means of a layer of silica aerogel reinforced with PET (Polyethylene terephthalate) fibers (felt), water-repellent and breathable, with mass density equal to $230 \mathrm{~kg} / \mathrm{m}^{3}$, thermal conductivity equal to $0.015 \mathrm{~W} / \mathrm{mK}$ and specific heat capacity equal to $1000 \mathrm{~J} / \mathrm{kgK}$. The external finish of the coat was realized with cement fiber panels, which are also mounted with dowels.
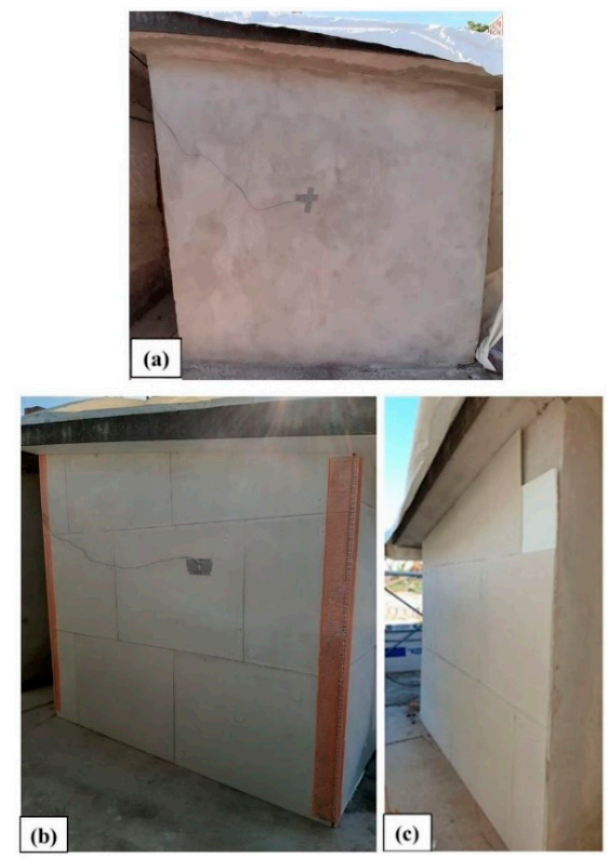

Figure 2. Selected test rooms in their original state (a) and during aerogel panel installation (b,c). 
As already mentioned, one of the test rooms was monitored as a reference structure for measurements, without any thermal insulation. The other was fully insulated with 0.01-m-thick aerogel panels.

In order to assess the thermal behavior of the reference test room and the insulated one, a heat flow meter sensor and internal and external surface and air temperature probes were installed on the walls [42-45] facing north-west. In particular, heat flow meter sensors were installed on the inner side of the walls, and surface temperature probes were installed on the inner and outer sides of the walls. In addition, internal and external air temperatures were monitored. The experimental campaign was carried out during the winter, specifically during January and February 2020. The schematic representation of the experimental setup is shown in Figure 3. Table 2 lists the technical specifications of the measuring instruments.

\section{WITHOUT INSULATION (a)}

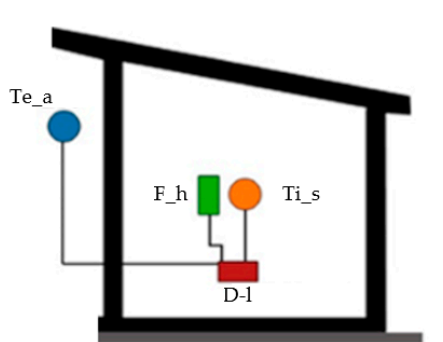

longitudinal section scheme

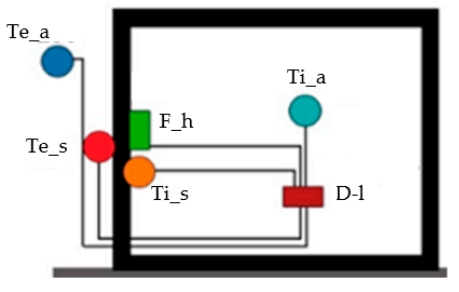

cross section scheme

WITH INSULATION PANEL (b)

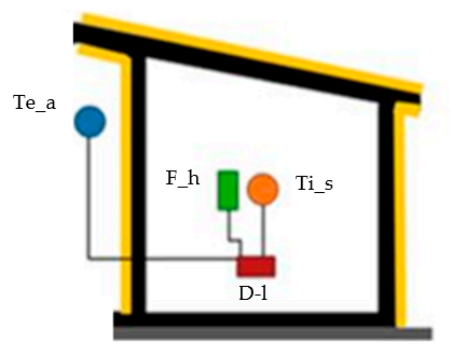

longitudinal section scheme

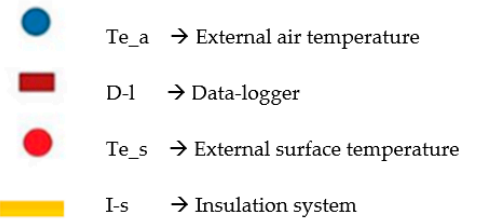

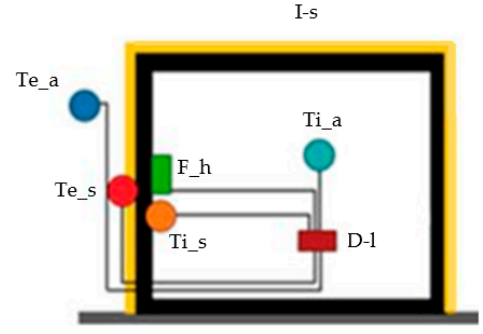

cross section scheme

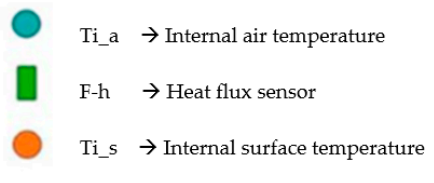

Figure 3. Schematic representation of the experimental setup in the reference test room (a) and in the insulated one (b).

Table 2. Technical Specifications of the Measuring Instruments.

\begin{tabular}{cccccc}
\hline Measuring Instrument & Manufacturer & Model & Measuring Range & Resolution & Accuracy \\
\hline $\begin{array}{c}\text { Heat-flow meter } \\
\text { Thermometer }\end{array}$ & Hukseflux & HFP01 & $\begin{array}{c}-2000 \div 2000 \\
\mathrm{~W} / \mathrm{m}^{2}\end{array}$ & $\begin{array}{c}0.01 \mathrm{~W} / \mathrm{m}^{2} \\
0.01{ }^{\circ} \mathrm{C}\end{array}$ & $\begin{array}{c}5 \% \text { on } 12 \mathrm{~h} \\
0.10^{\circ} \mathrm{C}\left(0^{\circ} \mathrm{C}\right)\end{array}$ \\
\hline $\begin{array}{c}\text { Surface temperature } \\
\text { probe }\end{array}$ & LSI & EST124 & $-40 \div 80^{\circ} \mathrm{C}$ & $0.01{ }^{\circ} \mathrm{C}$ & $0.15^{\circ} \mathrm{C}\left(0{ }^{\circ} \mathrm{C}\right)$ \\
\hline
\end{tabular}


The measurements of the thermal transmittances of the walls were carried out in compliance with the ISO 9869-1 Standard [46]. The acquired data were processed using the progressive averages method, applying the following formula:

$$
\mathbf{U}=\frac{\sum_{\mathbf{j}=1}^{\mathbf{n}} \mathbf{q}_{\mathbf{j}}}{\sum_{\mathbf{j}=1}^{\mathbf{n}}\left(\mathbf{T}_{\mathbf{a i}}-\mathbf{T}_{\mathbf{a e}}\right)_{\mathbf{j}}}
$$

where $\mathbf{q}$ is the heat flow density, $\mathbf{T}_{\mathbf{a i}}$ and $\mathbf{T}_{\mathbf{a e}}$ are the temperature of the air inside and outside the analyzed test room, respectively.

The phase shift (briefly defined PS) of the thermal waves can be determined as the time difference between the recording time of the highest external surface temperature value $\left(h_{-T s}\right.$ max $_{\mathrm{e}}$ ) compared to that which corresponds to the highest internal surface temperature $\left(\right.$ h_Ts $\left.\max _{\mathbf{i}}\right)$.

$$
\text { PS }=\mathbf{h}_{-} \text {Ts } \max _{\mathbf{e}}-\mathbf{h}_{-} \text {Ts } \max _{\mathbf{i}}
$$

The thermal wave attenuation (briefly defined DF) can be calculated as the ratio of the difference between the maximum internal surface temperature $\left(\mathbf{T}_{\mathbf{s}_{\text {max }_{i}}}\right)$ and the average one $\left(\mathbf{T}_{\mathbf{s}_{\mathbf{a v g}_{\mathrm{i}}}}\right)$, and the difference between the maximum external surface temperature $\left(\mathbf{T}_{\mathbf{s}_{\text {max }_{\mathbf{e}}}}\right)$ and the average one $\left(\mathbf{T}_{\mathbf{s a v g}_{\mathbf{e}}}\right)$ [47]:

$$
\mathrm{DF}=\left[\frac{\mathrm{T}_{\mathrm{s}_{\max _{\mathrm{i}}}}-\mathrm{T}_{\mathrm{s}_{\mathrm{avg}_{\mathrm{i}}}}}{\mathrm{T}_{\mathrm{s}_{\text {maxe }_{\mathrm{e}}}-\mathrm{T}_{\mathrm{savg}_{\mathrm{e}}}}}\right]
$$

In order to carry out a complete and reliable measurements campaign, the thermal behaviors of the two test rooms were analyzed taking into account different scenarios in terms of operational times of the heating system (made with electric fan heaters properly shielded to avoid direct disturbing effects to the sensors).

The first analyzed scenario took five days; during this time, the heating systems was always switched off (this first scenario is defined in the following as Free-Floating).

In the second scenario (the so-called $\mathrm{On}$ ), the heating systems were switched on for four days continuously, and at the end of this time, the cooling phase of the two structures was evaluated during the 3 following days.

Finally, in the third scenario (the so-called On-Off), the thermal behavior of the two structures was studied by switching on the heating systems for nine hours per day (switching on the fan heaters in the morning at 9.00 a.m. and switching them off at 06.00 p.m.).

\subsection{Energy Simulation Model}

The data obtained from the experimental campaign were employed to build a dynamic energy simulation model of an ideal building. The test rooms, in fact, are too small and not representative of a real residential building. The ideal building, which was used by the authors for simulations in previous works, has the same envelope thermal performance (thermal transmittance, phase shift, wave attenuation, etc.) as that of the monitored test rooms, but it is more representative of an actual building since it has transparent surfaces and plants that are essential in residential spaces.

An hourly energy simulation was performed using Design Builder software [48], a computational code based on Energy Plus as an internal simulation engine.

Design Builder was used for modeling a building larger than the actual buildings where measurements were carried out. A simple building with a square shape of a $6 \mathrm{~m}$ side, similar to a two-storey detached house already used in other studies [49], was considered as a case study (Figure 4). Each wall has a surface area equal to $36 \mathrm{~m}^{2}$, characterized by the stratigraphy listed previously in Table 1 . The fifteen windows adopted in the model are double glazed windows $(6 \mathrm{~mm}-6 \mathrm{~mm}$ filled with air in the gap and with a solar factor of $0.7)$, with a thermal transmittance of $3.094 \mathrm{~W} / \mathrm{m}^{2} \mathrm{~K}$ and an area of $1.44 \mathrm{~m}^{2}$ for each one; the frame is made of painted wood and is characterized by a thickness of $8 \mathrm{~cm}$. The shadings of the windows are composed by shutters that are simulated as external systems. 


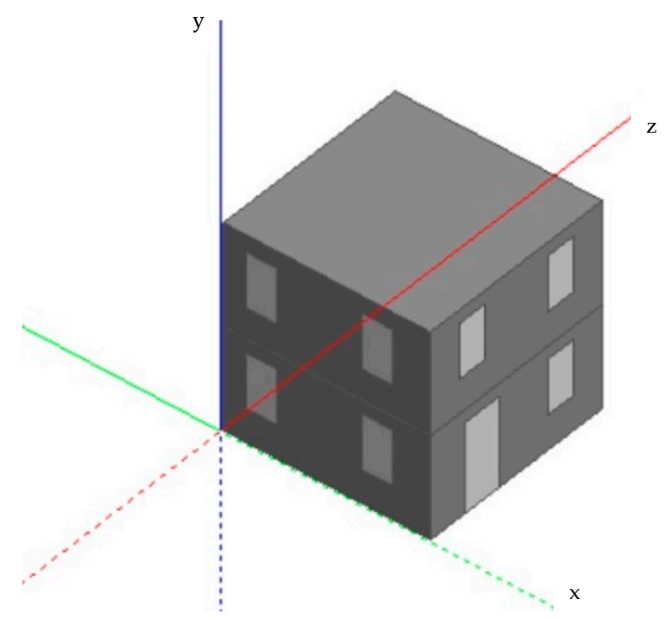

Figure 4. 3D view of the case study used for simulation.

The following settings were adopted:

- The internal gains were not considered, excluding the ones linked to people's metabolic rate that varies between 110 and $180 \mathrm{~W} /$ person depending on the activity performed in the different rooms; the employed metabolic rate factor was equal to 0.9 .

- $\quad$ The clothing was equal to 1 clo in winter and 0.5 clo in summer.

- $\quad$ The heating system schedule was 5-9 a.m. and 5-12 p.m.

- The infiltration rate considered was equal to $0.71 / \mathrm{h}$.

- The ventilation was natural and set to $11 / \mathrm{h}$.

- The internal set point temperature was set as equal to $20^{\circ} \mathrm{C}$ for winter.

As Italian buildings are usually equipped with only heating system, a natural gas boiler was supposed for the heat generation, and the global efficiency of the system was set as equal to 0.83 . In the energy model, an occupancy value of 0.02 people $/ \mathrm{m}^{2}$ has been defined.

The energy need of the building was simulated. Later, different insulating materials were tested, taking always into account a thickness of the insulating layer equal to $0.01 \mathrm{~m}$ (equal to the thickness of the aerogel panel tested during the in situ campaign). This choice allows the comparison of different insulation materials with equal saving of inner space in the case of internal application; the use of aerogel is, in fact, a competitive solution in the retrofit of historical buildings when the intervention on the external façade is not possible for architectural conservatory constraints [35]. In particular, the simulated insulating materials are: Expanded PolyStyrene (EPS), rock wool, kenaf and aerogel (whose thermophysical properties are shown in Table 3).

Table 3. Thermal characteristics, duration and decay rate of the aerogel and other materials.

\begin{tabular}{cccccc}
\hline Insulating & $\begin{array}{c}\text { Conductivity } \\
{[\mathbf{W} / \mathbf{m K}]}\end{array}$ & $\begin{array}{c}\text { Specific } \\
\text { Heat [J/kgK] }\end{array}$ & $\begin{array}{c}\text { Density } \\
{\left[\mathbf{k g} / \mathbf{m}^{3}\right]}\end{array}$ & $\begin{array}{c}\text { Duration } \\
{[\text { Years }]}\end{array}$ & $\begin{array}{c}\text { Decay Rate } \\
{[\%]}\end{array}$ \\
\hline $\begin{array}{c}\text { Expanded } \\
\text { PolyStyrene (EPS) }\end{array}$ & 0.040 & 1400 & 15 & 20 & 0.20 \\
Rock Wool & 0.038 & 840 & 40 & 25 & 0.25 \\
Kenaf & 0.040 & 1700 & 30 & 15 & 0.17 \\
Aerogel & 0.015 & 1000 & 230 & 45 & $0.21^{1}$ \\
\hline
\end{tabular}

${ }^{1}$ Obtained as the mean of other materials' decay rate. 
For the materials, a useful life of 45, 20, 25 and 15 years was considered, respectively, for aerogel, EPS, rock wool and kenaf. However, the materials may not be removed from the walls, and they could continue to partially carry out their task for the whole duration of the building. Therefore, for these kinds of interventions, a linear compound decay rate was estimated as equal to $0.21 \%, 0.20 \%, 0.25 \%$ and $0.17 \%$ per year, respectively, for aerogel, EPS, rock wool and kenaf (Table 3). As far as the duration is concerned, a duration of 50 years was considered for the building.

These insulating materials modified the walls' thermal transmittances, as reported in Table 4 (the insulating material is installed on the outer side of the wall, before plaster). According to this, an energy analysis was carried out to quantify the energy savings obtained by means of different insulating materials.

Table 4. U-Value of the Walls Considering Different Insulating Materials.

\begin{tabular}{cc}
\hline Wall & U-Value $\left[\mathbf{W} / \mathbf{m}^{2} \mathbf{K}\right]$ \\
\hline Original wall & 1.647 \\
Insulated with Expanded PolyStyrene (EPS) & 1.167 \\
Insulated with Rock Wool & 1.149 \\
Insulated with Kenaf & 1.167 \\
Insulated with Aerogel & 0.785 \\
\hline
\end{tabular}

\subsection{Environmental Assessment Based on LCA}

Following the quantification of the energy savings obtained after the implementation of different retrofits, a life cycle assessment (LCA) was performed to determine the effectiveness of the intervention when considering the environmental burdens embodied in the building materials installed. The LCA is an interesting methodology that permits the comparison of the energy requirements of the buildings and the related environmental burdens from a more comprehensive perspective that takes into account the whole life cycle stage of the constructions (production, installation, operation, end-of-life). In fact, different authors have already warned about the burden shifting that characterizes every retrofit intervention [50,51]: the reduction of the operational energy requirement and related environmental burdens is followed by an increase in embodied components linked to the installation of new building materials and systems. Two indicators were introduced to describe the environmental performances of the different external insulation coatings supposed: the Energy Payback Time (EPBT) and the Carbon Payback Time (CPBT). The first one can be defined as the ratio between the variation of the Embodied Energy $(\boldsymbol{E} E)$ of the building following the retrofit and the annual Energy Savings $(E S a)$ achieved through the retrofit (see Equation (4)). The latter is similarly the ratio between the variation of the Embodied Carbon $(E C)$ of the building and the annual emissions avoided $(C S a)$ through the retrofit (see Equation (5)).

$$
\begin{aligned}
& E P B T=\frac{\Delta E E}{E S a} \\
& C P B T=\frac{\Delta E C}{C S a}
\end{aligned}
$$

The LCA analysis was carried out using Ecoinvent (Ecoinvent, Zurich, Switzerland) data, and when this was not possible, Environmental Product Declaration datasheets were consulted [52]. The EE was calculated using the single-issue indicator Cumulative Energy Demand (CED), while the Global Warming Potential (GWP) (100 years) was employed to determine the EC of the retrofit. As shown in Figure 5, a "cradle to site" approach was employed for the life cycle assessment. Since the application of external insulation coatings in a low-height building does not imply an energy intensive installation process, stage A5 can be considered negligible. 


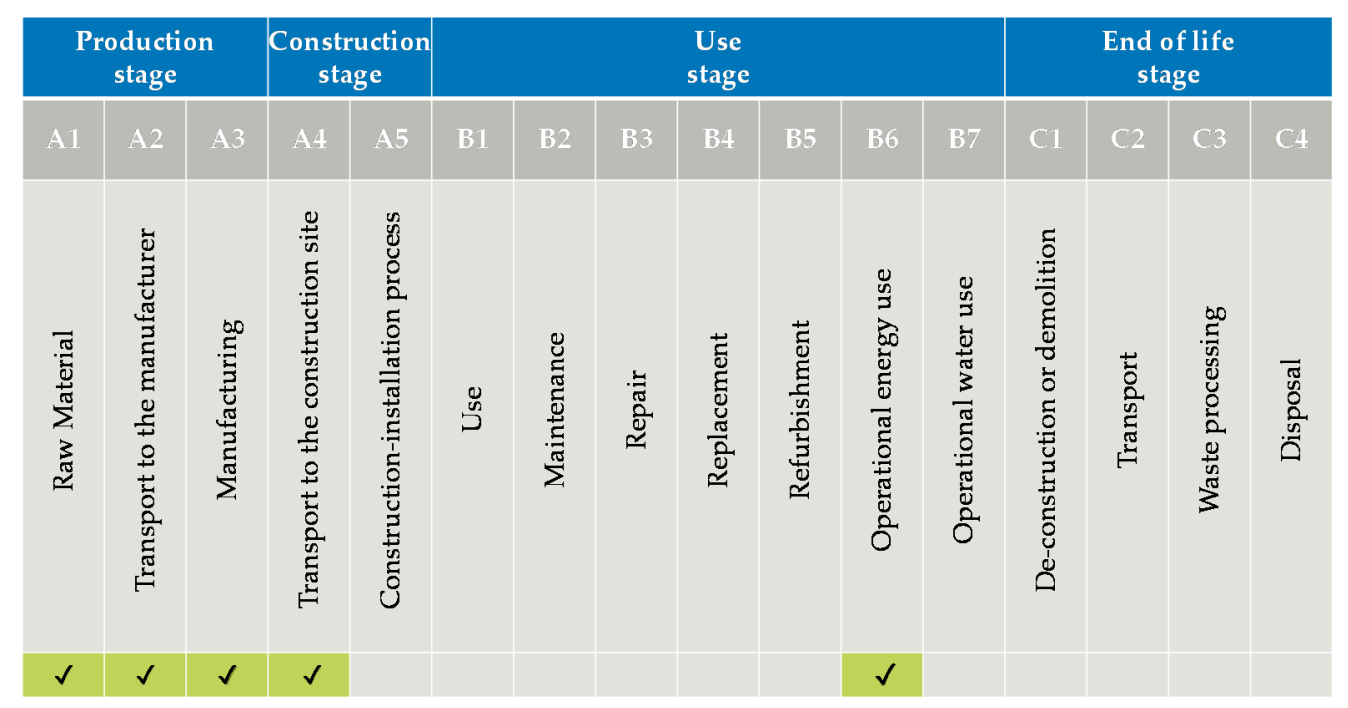

Figure 5. Life cycle stages considered in this study (green marked).

On the other hand stages B1-B5 were not included in the calculation of the payback times since, generally, they are much lower than the useful life adopted in this work for the insulation materials (see Table 3) [53].

\subsection{The Cost-Benefit Analysis}

From an economic-financial perspective, the international literature estimates the convenience of retrofit intervention in a partly incomplete manner.

Table 5 provides a systematic review of some typical studies.

The international literature on this topic is very ample and an in-depth analysis of it goes beyond the objective of this study. Therefore, only some studies are analyzed, which can be considered representative of different approaches.

Most studies consider only the energy savings resulting from retrofit interventions and some related items (initial investment, maintenance costs, running and replacement costs, etc.) which are measurable in monetary terms. They do not consider the environment benefits of a retrofit, nor, generally speaking, its impacts on the Internal Environmental Quality (IEQ), due to the difficulty and subjectivity of their economic measurement. 
Table 5. Studies on the Economic Convenience of a Retrofit Intervention.

\begin{tabular}{|c|c|c|c|c|c|c|c|c|c|c|c|c|c|c|}
\hline \multirow[b]{3}{*}{ Studies } & \multicolumn{14}{|c|}{ Main Characteristics } \\
\hline & \multicolumn{2}{|c|}{ Main Objective } & \multicolumn{2}{|c|}{$\begin{array}{c}\text { Decision Scenario } \\
\text { Considered }\end{array}$} & \multicolumn{4}{|c|}{ Performance Measure } & \multicolumn{3}{|c|}{ Costs and Benefits Considered } & \multirow[b]{2}{*}{$\begin{array}{l}\text { Uncertainty } \\
\text { Explicitly } \\
\text { Considered }\end{array}$} & \multicolumn{2}{|c|}{ Uncertain Variables } \\
\hline & $\begin{array}{l}\text { Methodological } \\
\text { (+Example } \\
\text { Case) }\end{array}$ & $\begin{array}{c}\text { Real } \\
\text { Specific } \\
\text { Applica- } \\
\text { tion }\end{array}$ & $\begin{array}{l}\text { Stand- } \\
\text { Alone } \\
\text { Investment } \\
\text { Conve- } \\
\text { nience }\end{array}$ & $\begin{array}{l}\text { Comparison } \\
\text { among } \\
\text { Alternative } \\
\text { Interven- } \\
\text { tions }\end{array}$ & $\begin{array}{l}\text { Payback } \\
\text { Period }\end{array}$ & $\begin{array}{l}\text { Discounted } \\
\text { Payback } \\
\text { Period (1) }\end{array}$ & $\begin{array}{c}\text { Present } \\
\text { Value of } \\
\text { Differential } \\
\text { Costs } \\
\text { (Pseudo } \\
\text { NPV or PI) } \\
\text { (1) (2) }\end{array}$ & NPV (3) & $\begin{array}{c}\text { Energy } \\
\text { Efficiency }\end{array}$ & LCC (4) & IEQ (5) & & Technical & Economic \\
\hline Almeida et al. [54] & $\mathrm{x}$ & & & $\mathrm{x}$ & & & $\mathrm{x}$ & & & $\mathrm{x}$ & & $\mathrm{x}$ & $\mathrm{x}$ & \\
\hline Ballarini et al. [56] & $\mathrm{x}$ & & & $\mathrm{x}$ & $\mathrm{x}$ & & $\mathrm{x}$ & & $\mathrm{x}$ & $\mathrm{x}$ & & $\mathrm{x}$ & $\mathrm{x}$ & \\
\hline Burhenne et al. [57] & $\mathrm{x}$ & & $\mathrm{x}$ & & & & $\mathrm{x}$ & & $\mathrm{x}$ & & & $\mathrm{x}$ & $\mathrm{x}$ & $\mathrm{x}$ \\
\hline Gustaffson [58] & $\mathrm{x}$ & & $\mathrm{x}$ & & & & $\mathrm{x}$ & & & $\mathrm{x}$ & & & & \\
\hline Hasan et al. [59] & & $\mathrm{x}$ & & $\mathrm{x}$ & & & $\mathrm{x}$ & & & $\mathrm{x}$ & & & & \\
\hline Hopfe-Hensen [60] & $\mathrm{x}$ & & & & & & & & & & & $\mathrm{x}$ & $\mathrm{x}$ & \\
\hline Niemela et al. [61] & & $\mathrm{x}$ & & $\mathrm{x}$ & $\mathrm{x}$ & & $\mathrm{x}$ & & & $\mathrm{x}$ & & $\mathrm{x}$ & & $\mathrm{x}$ \\
\hline Ortiz et al. [62] & & $\mathrm{x}$ & & $\mathrm{x}$ & & & $\mathrm{x}$ & & & $\mathrm{x}$ & & $\mathrm{x}$ & $\mathrm{x}$ & \\
\hline Ozel $[63,64]$ & & $\mathrm{x}$ & & $\mathrm{x}$ & & $\mathrm{x}$ & & & $\mathrm{x}$ & $\mathrm{x}$ & & $\mathrm{x}$ & $\mathrm{x}$ & \\
\hline Verbeeck-Hens [65] & & $\mathrm{x}$ & & $\mathrm{x}$ & $\mathrm{x}$ & & $\mathrm{x}$ & & $\mathrm{x}$ & & & & & \\
\hline
\end{tabular}

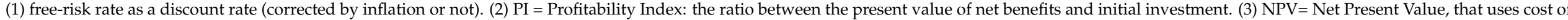
capital (risk-free rate + risk premium) as a discount rate. (4) LCC = Life-Cycle Costs. (5) IEQ = Indoor Environmental Quality. 
Some of them choose the intervention which guarantees the quickest recovery of the investment or the shortest payback time [55,56,61,63-65]. This method is quite easy to apply, but it shows two elements of weakness:

- It does not discount, with an appropriate cost of capital, the costs and benefits of the investment which occur in different years, often over very long periods, and that are estimates (i.e., uncertain values).

- It does not provide a threshold value with which to compare the recovery period of individual interventions (for a stand-alone evaluation of their convenience).

When a more complete approach is provided [54,57-59,62], the present value of differential costs/benefits is calculated (in $[55,56,61,65]$ as a further method) by using a free-risk rate for discounting (often corrected by the expected inflation rate), which does not take into account a premium for the risk of the discounted cash flows.

The analysis here conducted applies a financial approach consistent with the modern financial theory. The net present value (NPV) is used (however, only considering the monetary costs and benefits of a retrofit, in line with the international literature), which measures today's monetary value of the intervention, and it discounts the net cash flows by a rate which considers the time value of the money and the risk premium, calculated with reference to the main risk drivers of the investment. The retrofit is convenient if the NPV is non-negative, and it is the more convenient the higher its value.

Furthermore, a probabilistic approach was used to measure the risk of the NPV of each retrofit alternative. Many studies [54,56,57,60-64] explicitly consider the uncertainty, more often with regard to the technical variables than the economic ones. Some studies consider different possible values of technical input variables (rarely of economic variables, as for example the discount rate in [57,61] and the initial investment and gas price in [57]) and estimate the resulting range of outcome measure, others $[54,57,60]$ use very complex methods to deal with the uncertainty (various sensitivity analysis methods and Monte Carlo techniques), but they are quite methodological exercises: in fact, these techniques are very difficult to apply in a real context, since many of the necessary data cannot be realistically provided, and the approach is quite difficult for the decision-maker to understand.

In this paper, optimistic and pessimistic estimates of the uncertain drivers of NPV were assumed and defined in a subjective manner (i.e., on the basis of the analyst/decisionmaker's forecasts), and the corresponding range of NPV was measured. This analysis provides two useful results for a decision-maker:

- To identify which variable, that influences the investment's NPV, most affects its variability (sensitivity analysis).

- To derive an approximate measure of the risk of retrofit under some hypotheses [66]; in fact, the sensitivity analysis allows the estimation of the probability distribution of the NPV, which enables the decision-maker to choose better than in the case of a single value: the decision-maker can translate his/her risk aversion into a minimum acceptable percentage of non-negative values of the NPV and compare the percentage emerging from the NPV probability distribution with this threshold value [67].

Finally, as far as the IEQ aspects are concerned, a multi-criteria methodology (MCDA) is being developed that would measure for the different retrofit interventions the main descriptors of the IEQ in relative terms, with respect to the acceptable ranges defined by EU regulations. This approach would use linear optimization models in order to allow the decision-maker to compare the retrofit alternatives with each other and with the current state of a building.

\section{Results and Discussion}

\subsection{Experimental Campaign Results}

As mentioned before, the monitoring campaign was carried out during the winter, specifically during the months of January and February 2020, and it was focused on the assessment of the thermal behavior of the studied test rooms in three different scenarios: 
Free-Floating conditions (no heating in the two test rooms), the so-called On scenario (heating system always on) and the so-called On-Off scenario (heating system on only during a specific daily time interval). The obtained results during winter can be summarized as follows:

- Free-floating conditions: Data processing in this phase mainly focused on defining the thermal waves' phase-shift and attenuation according to Equations (2) and (3). In particular, the surface temperature values were analyzed, and their trend over time is reported in Figure 6, where the internal and external surface temperatures for the reference test room are called Tsi_ref and Tse_ref, respectively.

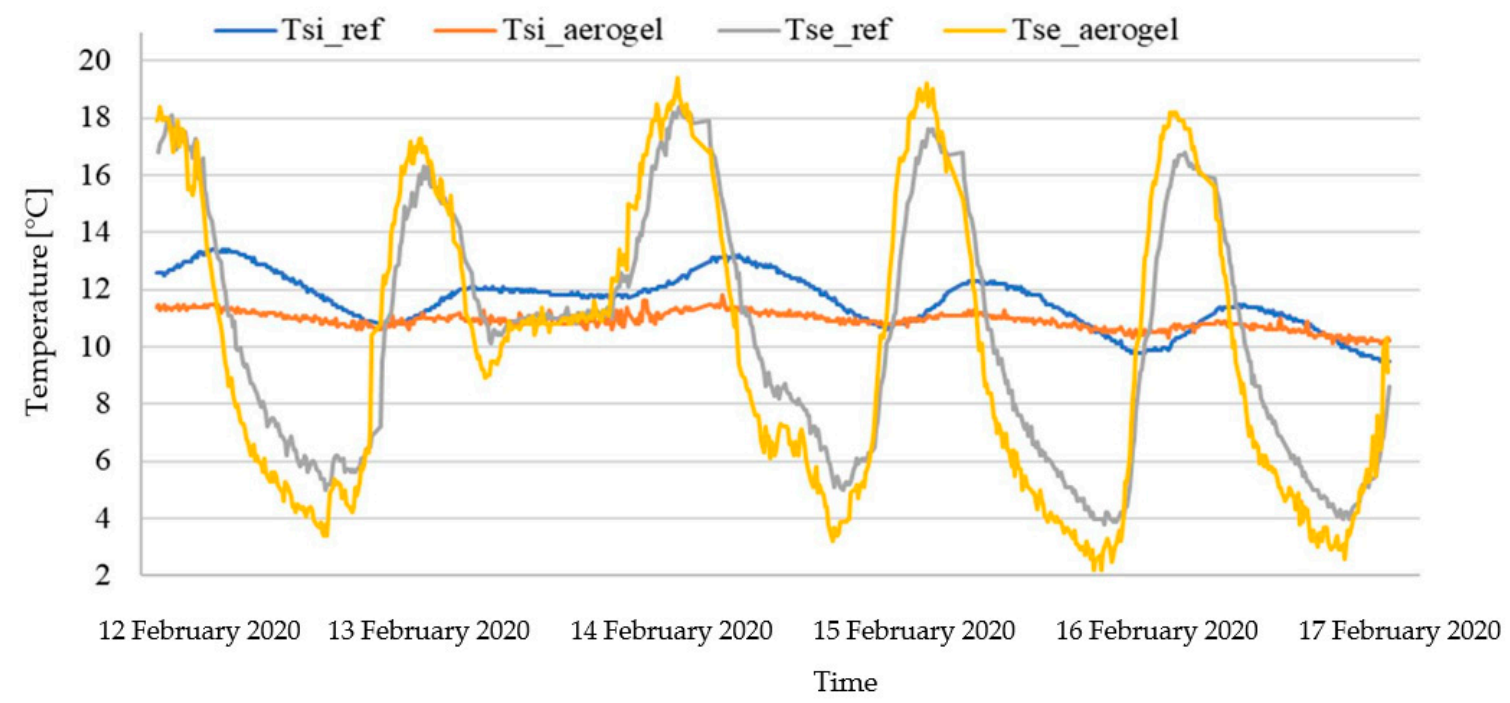

Figure 6. Internal and external surface temperatures of north-west walls registered for the insulated and the reference test rooms in the free-floating conditions.

On the other hand, the internal and external surface temperatures for the insulated test room are called Tsi_aerogel and Tse_aerogel, respectively.

It is clear that the internal surface temperatures immediately present a stabilized periodic regime. In particular, the internal surface temperature data measured on the thermally insulated test room provide almost constant values along time, mostly lower than those registered on the reference test room.

Both attenuation and phase shift values were calculated with respect to a daily interval, while the final average value (shown in Table 6) was calculated as the average of the daily attenuation and phase shift values.

Table 6. Attenuation and Phase-Shift Average Values Obtained under Free-Floating Conditions.

\begin{tabular}{|c|c|c|}
\hline & Attenuation & Phase Shift \\
\hline Reference Test Room & 0.124 & $4 \mathrm{~h} 07 \mathrm{~min}$ \\
\hline Thermally Insulated Test Room & 0.044 & $4 \mathrm{~h} 58 \mathrm{~min}$ \\
\hline
\end{tabular}

By comparing these data, it is possible to observe that applying a thin layer of aerogel does not cause a significant variation of the thermal inertia of the wall. In fact, the thermally insulated test room is characterized by an average phase shift just $20.6 \%$ higher than the reference one. On the contrary, one centimeter of aerogel, due to its high insulating performance, produced a decrease in the average attenuation of about $64.5 \%$ compared to that calculated for the reference test room, with a better indoor air temperature steadiness. Thus, it is possible to affirm that the application of a thin layer of aerogel can improve the dynamic behavior of the structure. However, this is not surprising. In a steady state regime, the layer arrangement makes no difference. On the contrary, under dynamic boundary 
conditions, the layer arrangement becomes fundamental, and by interchanging the layers the wall properties change. Hence, this aspect needs to be considered for improving the inertial behaviour of a wall.

- On scenario: The second phase was related to the investigation of the thermal behavior of the two test rooms with the heating always on. In this case, the progressive increase in the air temperature of the two different test rooms was focused, as shown in Figure 7 (before the vertical black dotted line).

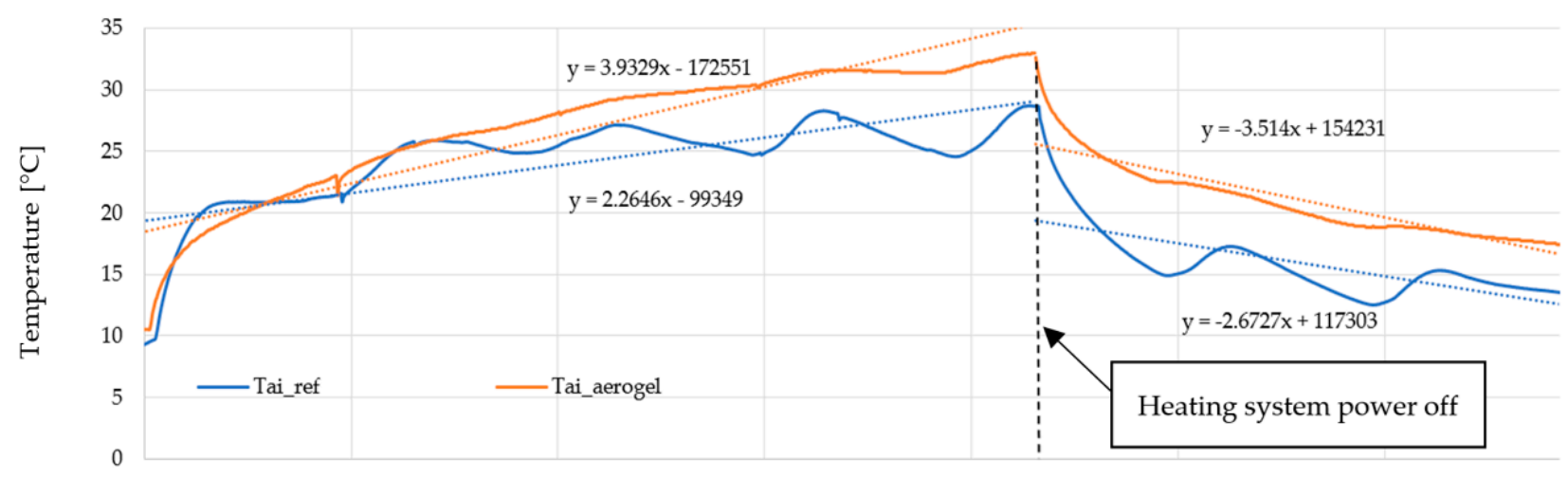

Figure 7. Indoor air temperatures registered in the test rooms during the second scenario.

Taking into account the thermally insulated test room, it is possible to observe a faster internal air temperature rise if compared with the reference test room. At the end of the always-on heating period, a stabilized regime was not achieved in the thermally insulated test room, as the internal temperature gradually increased. The use of the aerogel led to an internal air temperature of about $33^{\circ} \mathrm{C}$, compared to about $27^{\circ} \mathrm{C}$ (average value) obtained in the reference test room, where an almost periodic regime was identified after about two days.

The absence of the external insulating coat made the reference test room more sensitive to the typical variations of the outdoor air temperatures also during the heating system shutdown. Figure 7 (after the vertical black dotted line) shows a more rapid decrease in the values of the internal air temperature, as expected.

- On-Off scenario: The last part of the winter monitoring was aimed at evaluating the thermal behavior of the two test rooms, assuming that the heating system was switched on and off; i.e., switching on the fan heaters in the morning and switching them off in the evening, thus simulating the irregular working of an actual heating system. The acquired data were employed for evaluating the thermal transmittance of the walls facing north-west. Figure 8 shows the thermal transmittances as a result of the data post-processing based on the progressive average method. The thermal insulation of the test room through the thin layer of aerogel allowed obtaining a thermal transmittance reduction equal to $-28.3 \%$. 


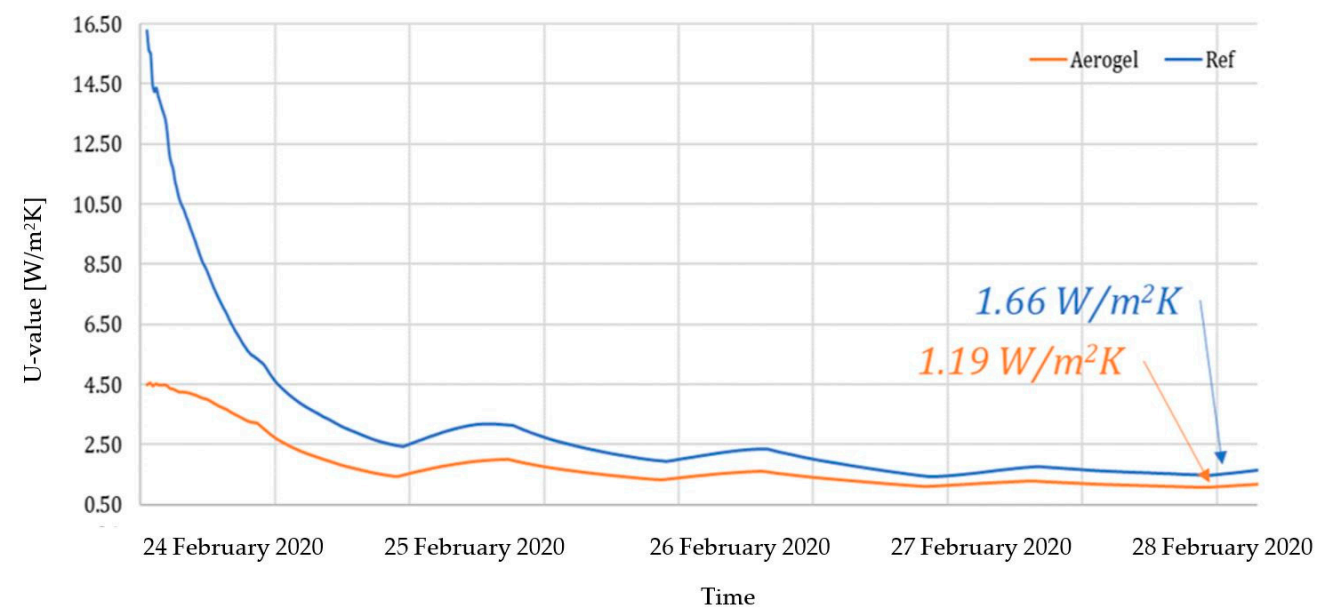

Figure 8. Thermal transmittances obtained from the U-value measurements.

\subsection{Energy and LCA Results}

Table 7 and Figure 9 show the results obtained through the software Design Builder. In the reference non-insulated building an energy demand for heating equal to 11,621.5 $\mathrm{kWh} /$ year of natural gas was obtained. The energy analysis shows how the installation of different insulating materials allows the reduction in the energy need of the building. Quite similar percentage reductions were obtained when the structure was insulated with EPS, rock wool and kenaf panels. Similar energy savings of about $6 \%$ are not surprising, because of similar thermal conductivity values among the different insulating materials. Aerogel, due to its reduced thermal conductivity, allowed achieving a heating energy need of 10,313.7 kwh/year. A percentage difference in terms of heating energy requirement equal to $-11.3 \%$ was obtained-almost double that obtained using the other insulating materials.

Table 7. Data on the Energy Need and Energy Saving of Insulated Buildings Compared with the Reference.

\begin{tabular}{cccccc}
\hline & Reference & EPS & Rock Wool & Kenaf & Aerogel \\
\hline Energy need [kWh] & $11,621.5$ & 10,945 & $10,917.7$ & $10,944.9$ & $10,313.7$ \\
Energy saving [\%] & - & -5.8 & -6.1 & -5.8 & -11.3 \\
\hline
\end{tabular}

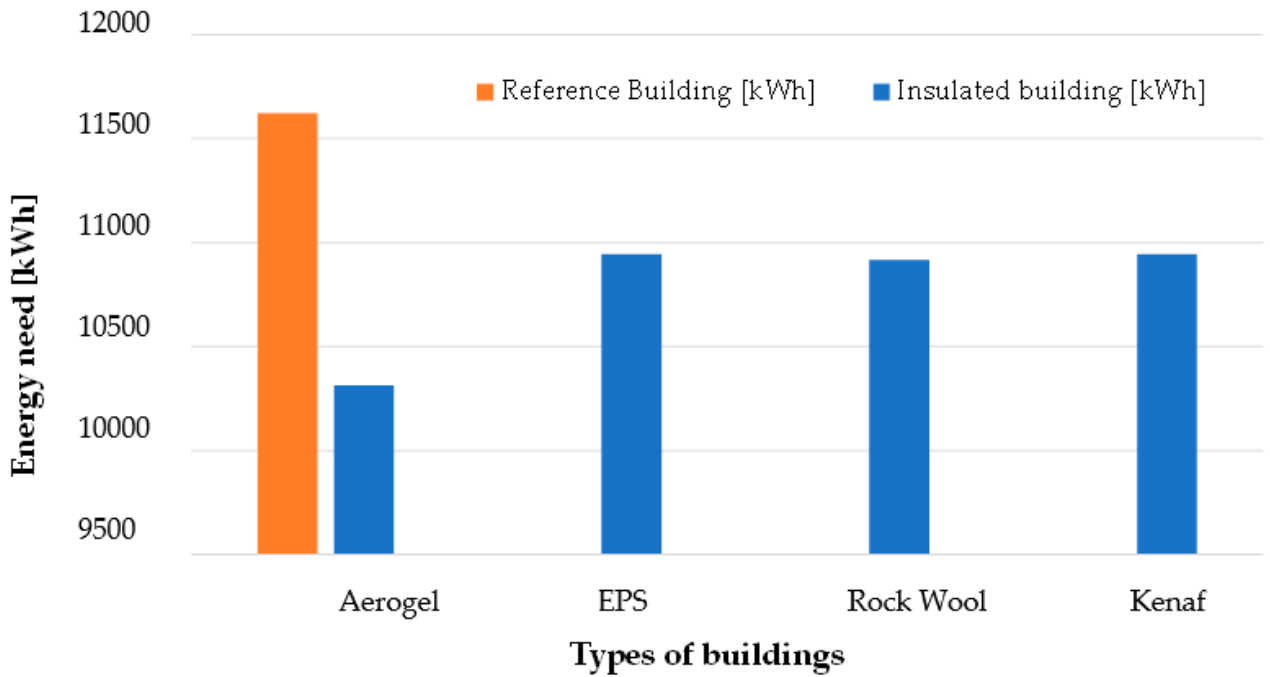

Figure 9. Energy needs of the reference building and the insulated one. 
The results on the EPBT and CBPT are reported in Table 8. The retrofit with aerogel is characterized by a higher EPBT and CPBT in comparison to traditional insulation materials (e.g., rock wool or EPS). As previously supposed in Section 3.3, the values obtained are lower than the supposed useful life of the insulation materials installed. This means that the burden shifting on embodied components is only temporary and that every intervention is characterized by a positive environmental effect on its life cycle. Figures 10 and 11 show the total CED and the cumulative GWP versus time considering as positive values the energy saved and the emissions avoided: the coating with traditional insulation materials has a lower payback time in comparison with the scenario considering aerogel as insulation material, but the latter results guarantee, after about fourteen years from the installation, a higher energy saving and carbon emission reduction potential.

Table 8. Energy and carbon payback times of the various retrofit solutions.

\begin{tabular}{ccccc}
\hline & $\begin{array}{c}\Delta \mathrm{EE} \\
\mathbf{( k W h )}\end{array}$ & $\mathbf{\Delta E C}\left(\mathbf{k g C O}_{\mathbf{2}} \mathbf{e q}\right)$ & $\begin{array}{c}\text { EPBT } \\
\text { (Years) }\end{array}$ & $\begin{array}{c}\text { CPBT } \\
\text { (Years) }\end{array}$ \\
\hline EPS & 1341 & 213 & 1.98 & 1.57 \\
Rock Wool & 1110 & 227 & 1.58 & 1.61 \\
Kenaf & 1793 & 323 & 2.65 & 2.38 \\
Aerogel & 9073 & 1682 & 6.94 & 6.40 \\
\hline
\end{tabular}

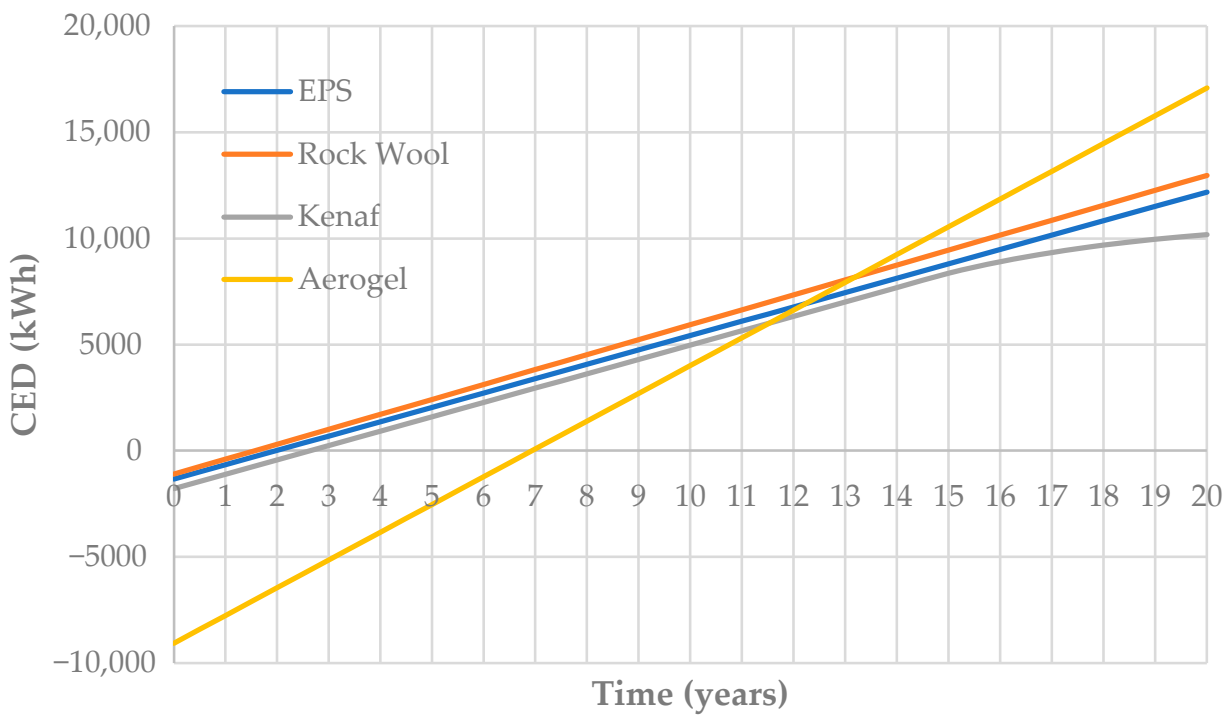

Figure 10. Cumulative energy demand for every retrofit intervention (positive values stand for energy saved). 


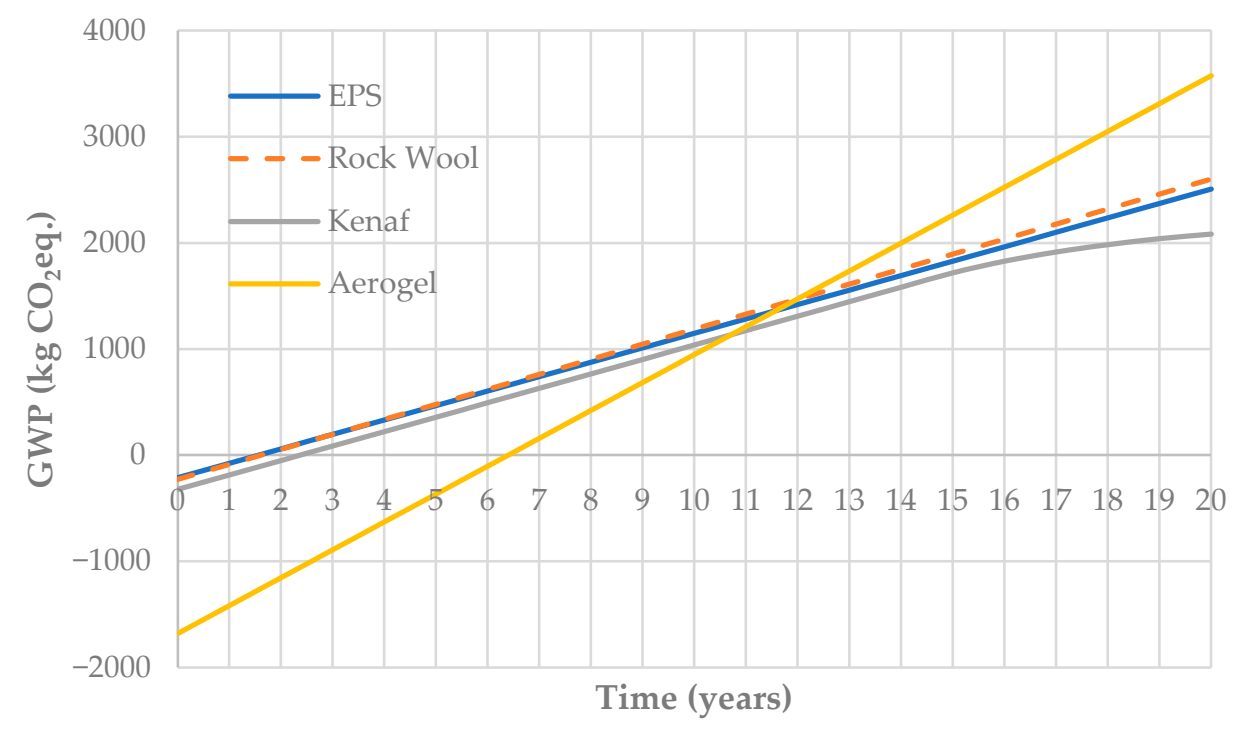

Figure 11. Cumulative GWP for every retrofit intervention (positive values stand for emissions avoided).

\subsection{Economic Analysis Results}

In order to calculate the NPV, the differential costs and benefits of the four analyzed materials (compared to the current state) were estimated.

In order to estimate benefits, the annual savings related to the methane gas consumption and the tax incentives of "Bonus Facciate" [68] were considered.

The price of methane gas was obtained by the average of prices applied by different suppliers in 2020, equal to 0.0985 euro per $\mathrm{kWh}$. From the historical price series of methane gas over the last 10 years (Eurostat data [69]), an annual growth rate of methane gas of $1.77 \%$ was obtained, applied during the whole duration of the retrofit (as a trend estimate).

For the duration and decay rates of the insulating materials, the values reported in Table 3 were adopted.

To estimate the tax incentives, based on the current regulation, a tax deduction of $90 \%$ of the total expenditure was assumed over 10 years.

To estimate the cost of capital, the Capital Asset Pricing Model approach has been used, with the following parameters:

- $\quad$ Risk free rate equal to $1.18 \%$, obtained from the average of the 10-year BTP returns during the last 12 months (investing data [70]); the rate includes both inflation expectations and country risk premium perceived by the market.

- Market risk premium equal to 5\% (IBES consensus estimate).

- Beta equal to 0.65 , estimated on the basis of the systematic variability of the methane gas price (source: Eurostat), referred to the Italian GDP (sources: Bank of Italy [71] and Istat [72]) from 1991 to today. The 1991-2019 time series of Italian GDP and methane gas price were considered, obtaining a variation coefficient (i.e., their normalized volatility) of $22.36 \%$ and $18.76 \%$, respectively; their Pearson coefficient of correlation is 0.77. Beta was calculated as Equations (6) and (7) show:

$$
\begin{gathered}
\text { beta }=\frac{\text { correlation }_{\text {gas price, } \mathrm{GDP}} \times \text { volatility }_{\text {gas price }}}{\text { volatility }_{\mathrm{GDP}}} \\
\text { beta }=\frac{0.77 \times 0.1876}{0.2236} \cong 0.65
\end{gathered}
$$

A cost of capital of $4.42 \%$ was obtained as Equations (8) and (9) show:

$$
\text { cost of capital }=\text { risk free rate }+ \text { beta } \times \text { market risk premium }
$$




$$
\text { cost of capital }=1.18+0.65 \times 5=4.42 \%
$$

which was used as a discount rate of the energy savings. The tax incentives were discounted by the risk-free interest rate since they are relatively certain. Table 9 summarizes the costs, benefits and NPV of the four materials.

Table 9. Calculation of the Net Present Value (NPV) of materials (data in euros).

\begin{tabular}{|c|c|c|c|c|}
\hline $\begin{array}{c}\text { Cash Flows and } \\
\text { NPV }\end{array}$ & Aerogel & EPS & Rock Wool & Kenaf \\
\hline $\begin{array}{c}\text { Present value } \\
\text { (energy savings) }\end{array}$ & 3510.50 & 1795.03 & 1871.13 & 1790.53 \\
\hline $\begin{array}{l}\text { Present value } \\
\text { (tax deduction) }\end{array}$ & $12,266.58$ & 4605.13 & 4708.38 & 5555.07 \\
\hline $\begin{array}{l}\text { Lump-sum } \\
\text { investment } 1\end{array}$ & $14,359.52$ & 5390.86 & 5511.74 & 6502.88 \\
\hline NPV & 1417.55 & 1009.30 & 1067.78 & 842.71 \\
\hline
\end{tabular}

${ }^{1}$ Estimated for a surface of $121 \mathrm{~m}^{2}$.

It is possible to conclude that in this scenario aerogel gives the best economic benefits, with a positive expected NPV of EUR 1417.55.

As far as the intervention risk is concerned, a sensitivity analysis was implemented for retrofit interventions of aerogel and rock wool (on the basis of the results of the previous analysis, the latter is the best among the alternatives to aerogel). Optimistic and pessimistic estimates of the main uncertain drivers of the NPV have been forecasted: duration, methane gas price, cost of capital and tax incentive. The assumptions were the following:

- The duration was included in the range of 45-50 years for aerogel and 20-30 for rock wool. The decay rate during the building residual duration was estimated as a linear compound decay rate from material duration to building duration (in contrast, in the case of aerogel, the average decay rate has been used: due to its longer duration, this hypothesis is more realistic).

- The methane gas price's change is equal to $\pm 13 \%$ (compared to 2020), measured on the basis of the price semiannual time series (Eurostat data). Gas price is assumed to be normally distributed, and the values corresponding to $5^{\circ}$ and $95^{\circ}$ percentiles of probability distribution are considered (this variation is added to the growth trend, hypothesized above).

- The cost of capital was included in the range $3.83-5.26 \%$, calculated as follows: (i) as an optimistic estimate, a risk-free rate equal to $1.59 \%$ and a beta of 0.53 were considered (the average beta of listed producers from Datastream [73] dataset was used); (ii) as a pessimistic estimate, the average beta of the gas industry (but including both gas producers and related service providers) and a risk-free rate equal to $1.56 \%$ were used. In this scenario, the risk-free rate was measured by adopting a more conservative approach; in fact, the German Bund 10-year returns were corrected by means of the inflation differential between Germany and Italy, and a country risk premium was added by using the differentials of credit default swap (CDS) spreads over 10 years (Bloomberg data [74]).

- Furthermore, in order to provide a more general assessment of the convenience of the different materials here considered, the current tax deduction of $90 \%$ has been assumed as an optimistic estimate: $50 \%$ and $65 \%$ are assumed as pessimistic and average tax incentives, respectively (all over 10 years). In this hypothesis (which is different from the current scenario, adopted in the above NPV calculation), given the most probable values of the other uncertain drivers discussed before, the most probable NPV of the two retrofits are negative, EUR -1989.83 and -240.11 , respectively.

- Table 10 shows the NPVs corresponding to the above estimates (changing a driver at a time) and the related NPV range. 
Table 10. Sensitivity Analysis of the NPV.

\begin{tabular}{|c|c|c|c|c|c|c|c|c|c|c|}
\hline \multicolumn{3}{|c|}{ Input Data } & \multicolumn{2}{|c|}{$\begin{array}{l}\text { NPV (Optimistic } \\
\text { Estimate) }^{1}\end{array}$} & \multicolumn{2}{|c|}{$\begin{array}{l}\text { NPV (Pessimistic } \\
\text { Estimate) }^{1}\end{array}$} & \multicolumn{2}{|c|}{ NPV Range ${ }^{1}$} & \multicolumn{2}{|c|}{$\begin{array}{l}\text { Coefficient of } \\
\text { Sensitivity }\end{array}$} \\
\hline $\begin{array}{l}\text { Uncertain } \\
\text { Drivers }\end{array}$ & $\begin{array}{l}\text { Optimistic } \\
\text { Estimate }\end{array}$ & $\begin{array}{l}\text { Pessimistic } \\
\text { Estimate }\end{array}$ & Aerogel & $\begin{array}{l}\text { Rock } \\
\text { Wool }\end{array}$ & Aerogel & $\begin{array}{l}\text { Rock } \\
\text { Wool }\end{array}$ & Aerogel & $\begin{array}{l}\text { Rock } \\
\text { Wool }\end{array}$ & Aerogel & $\begin{array}{l}\text { Rock } \\
\text { Wool }\end{array}$ \\
\hline $\begin{array}{c}\text { duration } \\
\text { (years) }\end{array}$ & $\begin{array}{l}\text { aerogel } 50 \\
\text { rock wool } 30\end{array}$ & $\begin{array}{l}\text { aerogel } 40 \\
\text { rock wool } 20\end{array}$ & -1988.71 & -235.83 & -1992.36 & -244.79 & 3.65 & 8.96 & $0.0 \%$ & $0.0 \%$ \\
\hline $\begin{array}{l}\text { methane price } \\
\qquad(\mathrm{kwh})\end{array}$ & 0.1113 & 0.0857 & -1533.46 & 3.14 & -2446.19 & -483.35 & 912.73 & 486.49 & $2.6 \%$ & $3.9 \%$ \\
\hline cost of capital & $3.83 \%$ & $5.26 \%$ & -1547.46 & 665.68 & -2495.91 & -563.10 & 948.44 & 1228.78 & $2.9 \%$ & $24.6 \%$ \\
\hline tax incentive & $90 \%$ & $50 \%$ & 1417.55 & 1067.78 & -4034.26 & -1024.84 & 5451.81 & 2092.61 & $94.5 \%$ & $71.5 \%$ \\
\hline
\end{tabular}

\footnotetext{
${ }^{1}$ Data in euros.
}

The last two columns measure the coefficients of NPV sensitivity; i.e., how much each driver variability influences the NPV variability.

Figure 12 shows the cumulative probability distribution of NPV of each retrofit, where NPV variance is measured following Equation (10) (by simplifying, the uncertain drivers are assumed to be independent of each other and linearly related to NPV):

$$
\sigma_{\mathrm{NPV}}^{2}=\sum k_{i}^{2} \times S_{i}^{2}
$$

where $S_{i}=$ NPV range between the optimistic estimate $U_{i}$ and the pessimistic one $L_{i}$ of uncertain driver $i$ (see columns 8-9 in Table 9) and, where $\sigma_{i}$ is its volatility (in this case, $k_{i}$ is equal to 0.3 ).

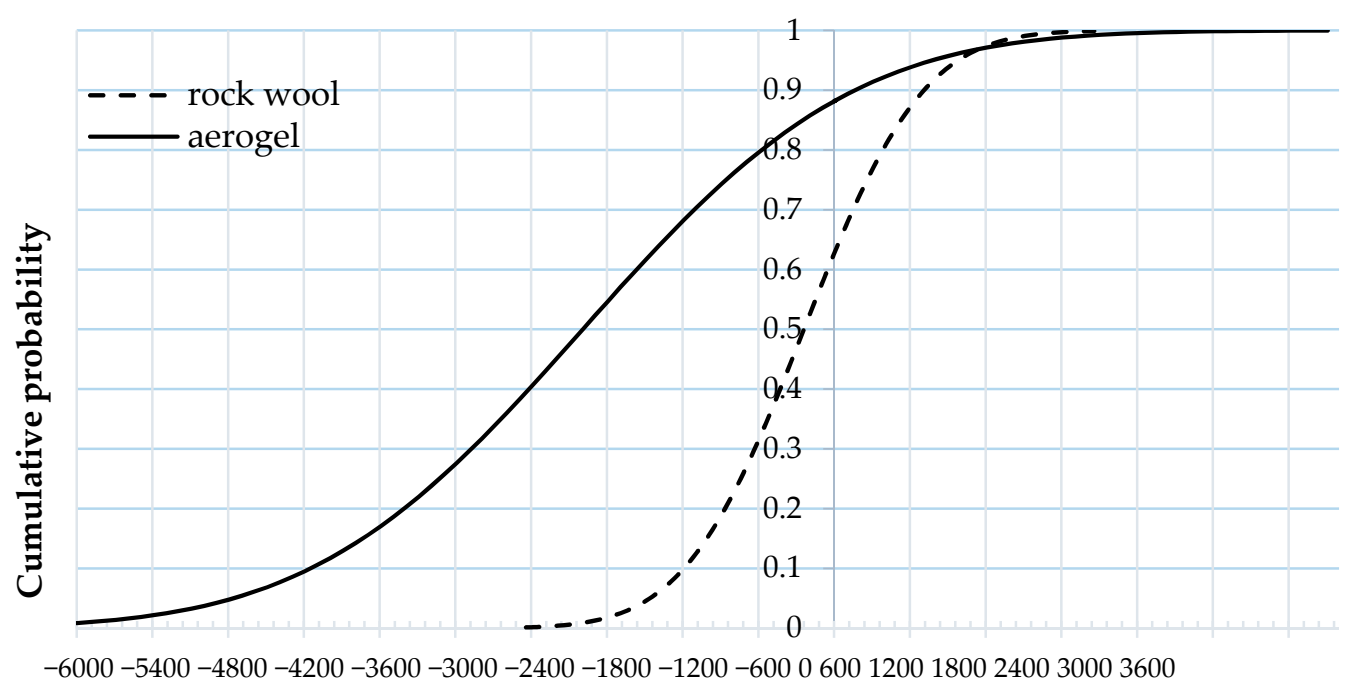

NPV

Figure 12. NPV cumulative probability distributions of retrofit with aerogel and rock wool.

The main results are the following:

- NPV volatility mainly depends on the change of tax incentive for both retrofits, which is the most important driver of performance and risk of the two retrofits considered here. The cost of capital affects NPV variance of rock wool retrofit more than aerogel retrofit (25\% versus $3 \%)$; the methane gas price volatility similarly affects NPV variance of two retrofits; the duration variability has no impact on both retrofits.

- Aerogel NPV assumes non-negative values in only $12 \%$ of the cases (rock wool in $38 \%$ of the cases, instead) and outperforms the competing material only in the right tail of the NPV probability distribution.

Due to the crucial effect of tax incentives on NPV of both retrofits here assessed, we further analyzed how NPV changes, depending on tax deduction (the most probable values 
of the other drivers were considered). Figure 13 shows that the aerogel NPV: (i) becomes the more advantageous, in comparison to rock wool, the higher the tax deduction; (ii) is positive for tax deduction larger than $80 \%$ (70\% for rock wool, instead); and (iii) beats the competing material when tax deduction is larger than $87 \%$. This analysis is important, since it shows that aerogel material is more convenient than competitors only in the fiscal framework here considered (or in a more favorable one, as for example in the case of the Superbonus $110 \%$ ), while in other scenarios it is not, due to its higher lump-sum investment (even though it provides double energy savings than the alternative materials).

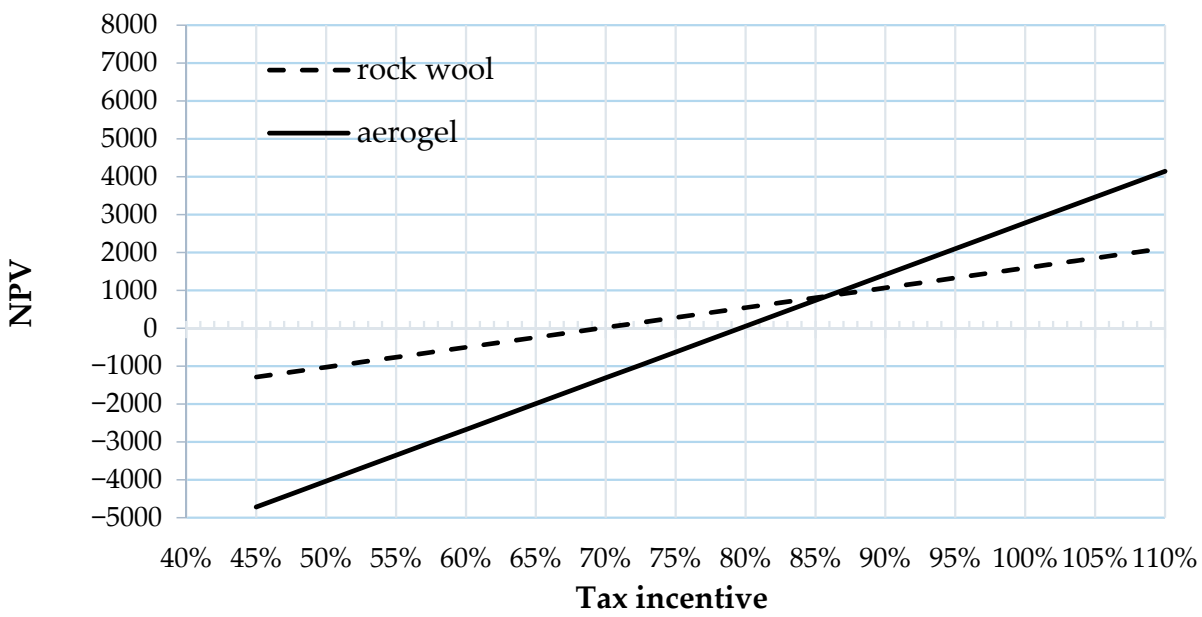

Figure 13. NPV as a function of tax incentives.

\section{Conclusions}

A small test room, totally insulated with aerogel panels, was investigated by an experimental point of view. The thermal behavior of the aerogel insulated test room was compared with a non-insulated identical test room. Heat transfers across walls were assessed by installing heat-flow meters and air and surface temperature sensors. Experimental data verified the well-known aerogel capability to improve the thermal performance of test room envelopes, even if reduced thicknesses of thermal insulation were applied. In particular, the thermally insulated test room showed an average phase shift $20.6 \%$ higher than the reference one. On the other hand, the small layer of aerogel allowed obtaining an average attenuation decrease of about $64.5 \%$ when compared to the reference test room. Moreover, $1 \mathrm{~cm}$ of aerogel allowed to obtain a thermal transmittance reduction of $-28.3 \%$.

Successively, a dynamic simulation model was generated to better comprehend the energy savings obtained through aerogel across a whole year, in terms of energy demand. By comparing aerogel with other commonly used insulation materials, a heating energy demand reduction of $-11.3 \%$ was found.

Subsequently, the investigation was completed by computing the environmental and energy payback times of this retrofit strategy as well as by a cost-benefit analysis through a probabilistic financial framework. In sum, it is possible to conclude that in the current tax incentive scenario the aerogel retrofit gives the best positive expected NPV, and from the whole LCA perspective it also guarantees both the highest energy saving and emissions avoidance. However, due to its higher lump-sum investment, aerogel's NPV is very sensitive to tax deductions and it is riskier than the best comparable material (roof wool) in less favorable tax scenarios: for example, if a $65 \%$ tax deduction is assumed (given the probability distributions of the uncertain variables considered here), aerogel gives a non-negative NPV only in $12 \%$ of the cases (roof wool in $38 \%$ of the cases, instead).

Therefore, the proposed interdisciplinary study aimed to investigate the environmental, energy and economic impacts associated with the application of aerogel compared to other insulating materials. Furthermore, the proposed methodological approach could also be replicated in other countries characterized by different climatic conditions. 
Future developments will address a comparison of the different energy, environmental and economic benefits of aerogel under different climatic conditions, also applying thin aerogel panels to different wall stratigraphy. In addition, the analysis could be performed also considering the energy, environmental and economic benefits of aerogel by analyzing walls thermally insulated with materials of different thicknesses but characterized by the same U-value.

Author Contributions: Conceptualization, P.M. (Paola Marrone), F.A. and D.V.; methodology, P.M. (Paola Marrone), F.A., D.V., L.F. and R.D.L.V.; thermal measurements, L.F., L.E., C.G., M.R. and F.O., energy simulations, G.G. and M.R.; economic-financial analysis: P.M. (Paolo Matteucci) and D.V.; data curation, L.E., C.G. and M.R.; writing-original draft preparation, L.E., C.G., M.R., F.O., P.M. (Paolo Matteucci) and D.V.; writing—review and editing, F.A., M.R., G.G., L.E., P.M. (Paolo Matteucci) and D.V.; supervision, P.M. (Paola Marrone), F.A., D.V., L.F. and R.D.L.V.; project coordination, P.M. (Paola Marrone). All authors have read and agreed to the published version of the manuscript.

Funding: This research received no external funding.

Institutional Review Board Statement: Not applicable.

Informed Consent Statement: Not applicable.

Data Availability Statement: Data available on request due to restrictions. The data presented in this study are available on request from the corresponding author. The data are not publicly available due to privacy reasons.

Acknowledgments: The authors would like to thank Eng. Alfredo Simonetti and all the staff at CEFME CTP for the valuable collaboration.

Conflicts of Interest: The authors declare no conflict of interest.

\section{References}

1. IPCC. Global Warming of $1.5^{\circ} \mathrm{C}$. Available online: https:/ /www.ipcc.ch/sr15 (accessed on 27 September 2020).

2. United Nations UNSD. Environmental Indicators. Available online: https://unstats.un.org/unsd/envstats/qindicators.cshtml (accessed on 14 November 2020).

3. European Commission. Paris Agreement. Available online: https://ec.europa.eu/clima/policies/international/negotiations/ paris_it (accessed on 14 November 2020).

4. United Nations. Environment Programme The Emissions Gap Report 2018. Available online: https://www.unenvironment.org/ resources/emissions-gap-report-2018 (accessed on 14 November 2020).

5. Sanson, A.; Giuffrida, L.G. Decarbonizzazione Dell'economia Italiana, il Catalogo Delle Tecnologie Energetiche. Available online: https:/ /www.dsctm.cnr.it/images/Eventi_img/de_carbonizzazione_3_ottobre_2017/catalogo-tecnologie-energetichevers. ultima.pdf (accessed on 14 November 2020).

6. Pomponi, F.; Moncaster, A. Circular economy for the built environment: A research framework. J. Clean. Prod. 2017, 143, 710-718. [CrossRef]

7. Geissdoerfer, M.; Savaget, P.; Bocken, N.M.P.; Hultink, E.J. The Circular Economy-A new sustainability paradigm? J. Clean. Prod. 2017, 143, 757-768. [CrossRef]

8. De los Rios, I.C.; Charnley, F.J.S. Skills and capabilities for a sustainable and circular economy: The changing role of design. J. Clean. Prod. 2017, 160, 109-122. [CrossRef]

9. Winans, K.; Kendall, A.; Deng, H. The history and current applications of the circular economy concept. Renew. Sustain. Energy Rev. 2017, 68, 825-833. [CrossRef]

10. Orsini, F; Marrone, P. Approaches for a low-carbon production of building materials: A review. J. Clean. Prod. 2019, 241, 118380. [CrossRef]

11. Orsini, F; Marrone, P. Prodotti a basse emissioni di carbonio: Potenzialità e limiti della manifattura della regione Lazio. In XIX Congresso Nazionale CIRIAF-Energia e Sviluppo Sostenibile; Morlacchi Editore University Press: Perugia, Italy, 2019; pp. 173-186.

12. Chitnis, M.; Sorrell, S.; Druckman, A.; Firth, S.; Jackson, T. Estimating Direct and Indirect Rebound Effects for U. S. Households. Available online: http:/ / www.sustainablelifestyles.ac.uk/sites/default/files/publicationsdocs/slrg_working_paper_01-12.pdf (accessed on 8 November 2020).

13. IEA. World Energy Outlook. 2018. Available online: https://www.iea.org/reports/world-energy-outlook-2018 (accessed on 8 November 2020).

14. European Commission. Secretariat-General Communication from the Commission to the European Parliament, the European Council, the Council, the European Economic and Social Committee and the Committee of the Regions-The European Green Deal Green Deal; European Commission: Brussels, Belgium, 2019. 
15. McKinsey \& Company Pathways to a Low-Carbon Economy: Version 2 of the Global Greenhouse Gas Abatement Cost Curve 2009. Available online: https://www.mckinsey.com/ $\{$ /media/mckinsey/dotcom/client_service/sustainability/costcurvepdfs/ pathways_lowcarbon_economy_version2.ashx (accessed on 8 November 2020).

16. Evangelisti, L.; Guattari, C.; Asdrubali, F. On the sky temperature models and their influence on buildings energy performance: A critical review. Energy Build. 2019, 183, 607-625. [CrossRef]

17. Papadopoulos, A.M. State of the art in thermal insulation materials and aims for future developments. Energy Build. 2005, 37, 77-86. [CrossRef]

18. Cuce, E.; Riffat, S.B. A state-of-the-art review on innovative glazing technologies. Renew. Sustain. Energy Rev. 2015, 41, 695-714. [CrossRef]

19. Aegerter, M.A.; Leventis, N.; Koebel, M.M. Aerogels Handbook; Springer: New York, NY, USA, 2011; ISBN 978-1-4419-7477-8.

20. Hüsing, N.; Schubert, U. Aerogels-Airy Materials: Chemistry, Structure, and Properties. Angew. Chem. Int. Ed. 1998, 37, 22-45. [CrossRef]

21. Lee, S.W.; Lim, C.H.; Salleh, E.; Ilias, B. Reflective thermal insulation systems in building: A review on radiant barrier and reflective insulation. Renew. Sustain. Energy Rev. 2016, 65, 643-661. [CrossRef]

22. Tenpierik, M.J.; Hasselaar, E. Reflective multi-foil insulations for buildings: A review. Energy Build. 2013, 56, 233-243. [CrossRef]

23. Aditya, L.; Mahlia, T.M.I.; Rismanchi, B.; Ng, H.M.; Hasan, M.H.; Metselaar, H.S.C.; Muraza, O.; Aditiya, H.B. A review on insulation materials for energy conservation in buildings. Renew. Sustain. Energy Rev. 2017, 73, 1352-1365. [CrossRef]

24. Karami, P.; Al-Ayish, N.; Gudmundsson, K. A comparative study of the environmental impact of Swedish residential buildings with vacuum insulation panels. Energy Build. 2015, 109, 183-194. [CrossRef]

25. Baetens, R.; Jelle, B.P.; Gustavsen, A.; Grynning, S. Gas-filled panels for building applications: A state-of-the-art review. Energy Build. 2010, 42, 1969-1975. [CrossRef]

26. Richter, K.; Norris, P.M.; Tien, C.-L. Aerogels: Applications, structure and heat transfer phenomena. Annu. Rev. Heat Transf. 1995, 6, 61-114. [CrossRef]

27. Kistler, S.S. Coherent Expanded Aerogels and Jellies. Nature 1931, 127, 741. [CrossRef]

28. Kistler, S.S.; Caldwell, A.G. Thermal Conductivity of Silica Aërogel. Ind. Eng. Chem. 1934, 26, 658-662. [CrossRef]

29. Koebel, M.; Rigacci, A.; Achard, P. Aerogel-based thermal superinsulation: An overview. J. Sol Gel Sci. Technol. 2012, 63, 315-339. [CrossRef]

30. Baetens, R.; Jelle, B.P.; Gustavsen, A. Aerogel insulation for building applications: A state-of-the-art review. Energy Build. 2011, 43, 761-769. [CrossRef]

31. Garay Martinez, R.; Goiti, E.; Reichenauer, G.; Zhao, S.; Koebel, M.; Barrio, A. Thermal assessment of ambient pressure dried silica aerogel composite boards at laboratory and field scale. Energy Build. 2016, 128, 111-118. [CrossRef]

32. Jensen, K.I.; Kristiansen, F.H.; Schultz, J.M. Highly Insulating and Light Transmitting Aerogel Glazing for Super-Insulating Windows: HILIT+ Public Final Report 2005. Available online: http://www.vinduesvidensystem.dk/Artikler-RapporterNoter-mm/Rapporter/HighlyInsulatingandLIghtTransmittingAerogelGlazingforSuperInsulatingWindows.pdf (accessed on 8 November 2020).

33. Buratti, C.; Moretti, E. Glazing systems with silica aerogel for energy savings in buildings. Appl. Energy 2012, 98, 396-403. [CrossRef]

34. Cuce, E.; Cuce, P.M.; Wood, C.J.; Riffat, S.B. Toward aerogel based thermal superinsulation in buildings: A comprehensive review. Renew. Sustain. Energy Rev. 2014, 34, 273-299. [CrossRef]

35. Orsini, F.; Marrone, P.; Asdrubali, F.; Roncone, M.; Grazieschi, G. Aerogel insulation in building energy retrofit. Performance testing and cost analysis on a case study in Rome. Energy Rep. 2020, 6, 56-61. [CrossRef]

36. Karim, A.N.; Johansson, P.; Kalagasidis, A.S. Super insulation plasters in renovation of buildings in Sweden: Energy efficiency and possibilities with new building materials. IOP Conf. Ser. Earth Environ. Sci. 2020, 588, 042050. [CrossRef]

37. Buratti, C.; Belloni, E.; Merli, F.; Zinzi, M. Aerogel glazing systems for building applications: A review. Energy Build. 2021, 231, 110587. [CrossRef]

38. Riffat, S.B.; Qiu, G. A review of state-of-the-art aerogel applications in buildings. Int. J. Low Carbon Technol. 2013, 8, 1-6. [CrossRef]

39. Italian Revenue Agency. Circolare n. 2/2020-Detrazione per gli interventi finalizzati al recupero o restauro della facciata esterna degli edifici esistenti prevista dall'articolo 1, commi da 219 a 224 della legge 27 dicembre 2019 n. 160 (Legge di bilancio 2020). Available online: https:/ / www.agenziaentrate.gov.it/portale/documents/20143/2338359/Circolare+n.+2+del+14+febbraio+ 2020.pdf/cee7f814-8750-9d6d-05ca-46d485c6470f (accessed on 8 November 2020).

40. President of Italian Republic Law Decree of 19 May 2020, Number 34-Article 119. Available online: https://www. gazzettaufficiale.it/eli/id/2020/05/19/20G00052/sg (accessed on 8 November 2020).

41. Ama Composites Aeropan Nanotech Thermal Insulation. Available online: http://www.aeropan.it/it/prodotti/aeropan/ (accessed on 8 November 2020).

42. Evangelisti, L.; Guattari, C.; Grazieschi, G.; Roncone, M.; Asdrubali, F. On the energy performance of an innovative green roof in the mediterranean climate. Energies 2020, 13, 5163. [CrossRef]

43. Evangelisti, L.; Guattari, C.; Gori, P.; De Lieto Vollaro, R.; Asdrubali, F. Experimental investigation of the influence of convective and radiative heat transfers on thermal transmittance measurements. Int. Commun. Heat Mass Transf. 2016, 78, 214-223. [CrossRef] 
44. Evangelisti, L.; Guattari, C.; Asdrubali, F. Comparison between heat-flow meter and Air-Surface Temperature Ratio techniques for assembled panels thermal characterization. Energy Build. 2019, 203, 109441. [CrossRef]

45. Evangelisti, L.; Guattari, C.; Asdrubali, F. Influence of heating systems on thermal transmittance evaluations: Simulations, experimental measurements and data post-processing. Energy Build. 2018, 168, 180-190. [CrossRef]

46. International Organization for Standardization. ISO 9869-1:2014 Thermal Insulation-Building Elements-In-Situ Measurement of Thermal Resistance and Thermal Transmittance Heat Flow Meter Method; ISO: Geneva, Switzerland, 2014.

47. Kontoleon, K.J.; Bikas, D.K. The effect of south wall's outdoor absorption coefficient on time lag, decrement factor and temperature variations. Energy Build. 2007, 39, 1011-1018. [CrossRef]

48. DesignBuilder Software Ltd. DesignBuilder, Version 6.1.5.004. Available online: http:/ / designbuilderitalia.it (accessed on 16 October 2020).

49. Grazieschi, G.; Gori, P.; Lombardi, L.; Asdrubali, F. Life cycle energy minimization of autonomous buildings. J. Build. Eng. 2020, 30, 101229. [CrossRef]

50. Ramesh, T.; Prakash, R.; Shukla, K.K. Life cycle energy analysis of buildings: An overview. Energy Build. 2010, 42, 1592-1600. [CrossRef]

51. Chastas, P.; Theodosiou, T.; Bikas, D. Embodied energy in residential buildings-towards the nearly zero energy building: A literature review. Build. Environ. 2016, 105, 267-282. [CrossRef]

52. Aspen Aerogels Inc. Environmental Product Declaration SPACELOFT®Aerogel Insulation. Available online: https://www. environdec.com/Detail/?Epd=10953 (accessed on 8 November 2020).

53. Asdrubali, F.; Ballarini, I.; Corrado, V.; Evangelisti, L.; Grazieschi, G.; Guattari, C. Energy and environmental payback times for an NZEB retrofit. Build. Environ. 2019, 147, 461-472. [CrossRef]

54. Almeida, R.M.S.F.; Ramos, N.M.M.; Manuel, S. Towards a methodology to include building energy simulation uncertainty in the Life Cycle Cost analysis of rehabilitation alternatives. J. Build. Eng. 2015, 2, 44-51. [CrossRef]

55. Almeida, R.M.S.F.; De Freitas, V.P. An Insulation Thickness Optimization Methodology For School Buildings Rehabilitation Combining Artificial Neural Networks And Life Cycle Cost. J. Civ. Eng. Manag. 2016, 22, 915-923. [CrossRef]

56. Ballarini, I.; Corrado, V.; Madonna, F.; Paduos, S.; Ravasio, F. Energy refurbishment of the Italian residential building stock: Energy and cost analysis through the application of the building typology. Energy Policy 2017, 105, 148-160. [CrossRef]

57. Burhenne, S.; Tsvetkova, O.; Jacob, D.; Henze, G.P.; Wagner, A. Uncertainty quantification for combined building performance and cost-benefit analyses. Build. Environ. 2013, 62, 143-154. [CrossRef]

58. Gustafsson, S.-I. Optimisation of insulation measures on existing buildings. Energy Build. 2000, 33, 49-55. [CrossRef]

59. Hasan, A.; Vuolle, M.; Sirén, K. Minimisation of life cycle cost of a detached house using combined simulation and optimisation. Build. Environ. 2008, 43, 2022-2034. [CrossRef]

60. Hopfe, C.J.; Hensen, J.L.M. Uncertainty analysis in building performance simulation for design support. Energy Build. 2011, 43, 2798-2805. [CrossRef]

61. Niemelä, T.; Kosonen, R.; Jokisalo, J. Cost-effectiveness of energy performance renovation measures in Finnish brick apartment buildings. Energy Build. 2017, 137, 60-75. [CrossRef]

62. Ortiz, J.; Fonseca i Casas, A.; Salom, J.; Garrido Soriano, N.; Fonseca i Casas, P. Cost-effective analysis for selecting energy efficiency measures for refurbishment of residential buildings in Catalonia. Energy Build. 2016, 128, 442-457. [CrossRef]

63. Ozel, M. Cost analysis for optimum thicknesses and environmental impacts of different insulation materials. Energy Build. 2012, 49, 552-559. [CrossRef]

64. Ozel, M. Determination of optimum insulation thickness based on cooling transmission load for building walls in a hot climate. Energy Convers. Manag. 2013, 66, 106-114. [CrossRef]

65. Verbeeck, G.; Hens, H. Energy savings in retrofitted dwellings: Economically viable? Energy Build. 2005, 37, 747-754. [CrossRef]

66. Hull, J.C. The Evaluation of Risk in Business Investment; Elsevier: New York, USA, 1980; ISBN 9780080240749.

67. Berk, J.; De Marzo, P.; Venanzi, D. Capital Budgeting; Pearson-Addison Wesley: Milan, Italy, 2009; ISBN 9788871925875.

68. Italian Parliament Law 27 December 2019, n. 160-Bilancio di Previsione Dello Stato per L'anno Finanziario 2020 e Bilancio Pluriennale per il Triennio 2020-2022. Available online: https://www.gazzettaufficiale.it/eli/id/2019/12/30/19G00165/sg (accessed on 8 November 2020).

69. Eurostat Energy Database. Available online: https:/ / ec.europa.eu/eurostat/web/energy/data/database (accessed on 8 November 2020).

70. Fusion Media Limited. Rates Italian Bonds: 10 Year Bond Yield. Available online: https://it.investing.com/rates-bonds/italy-10 -year-bond-yield (accessed on 8 November 2020).

71. Bank of Italy. Historical Series of the Bank of Italy-Statistical Series. Available online: https://www.bancaditalia.it/ pubblicazioni / collana-storica/statistiche/index.html (accessed on 8 November 2020).

72. Italian National Institute of Statistics (ISTAT). Italian National Gross Domestic Product. Available online: https:/ /www.istat.it/ it/archivio/pil (accessed on 8 November 2020).

73. Refinitiv Datastream. Available online: https:/ / eikon.thomsonreuters.com/index.html (accessed on 8 November 2020).

74. Bloomberg Finance, L.P. Credit Default Swap: 10 Years Spreads. Available online: https://bba.bloomberg.net/ (accessed on 8 November 2020). 